\title{
ON TEMPORALLY BOUNDED QUANTIFICATION OVER EVENTUALITIES
}

\author{
Telmo Móia, \\ Faculdade de Letras da Universidade de Lisboa / ONSET-CEL \\ tmoia@netcabo.pt
}

\begin{abstract}
This paper focuses on different subtypes of constructions involving temporally bounded quantification, e.g. sequences like David visited Rome three times followed by temporal phrases as different as (i) last year, which defines a time interval; (ii) in less that two months, which defines an amount of time; and (iii) per month, which refers to a time unit. As for the first two types of temporal phrases, data will be presented which shows that they have specific linguistic properties in these quantifying contexts, and do not behave exactly as the locating or duration adverbials they are superficially identical with. The third type of phrases will receive special attention. Structures with frequency adverbials like $n$ times per month will be analysed compositionally, separating the quantified component $n$ times from the temporally binding phrase per month (whose role is comparable to that of adverbials (i) and (ii) in the relevant constructions). The data presented is mainly from Portuguese, although the issues at stake - the linguistic properties of temporally bounded quantification - are obviously relevant to parallel constructions in other languages.
\end{abstract}

\section{Introduction}

This paper concentrates on a subclass of temporal constructions with quantification over eventualities, namely those where the quantification is relative to a time parameter - either a time interval, an amount of time, or a time unit -, as in the following examples:

(1) O David visitou Roma três vezes \{o ano passado / em menos de dois meses / por ano\}. "the David visited Rome three times \{ the year past / in less of two months / per year" David visited Rome three times \{last year / in less than two months / per year\}.

The structure of the paper is as follows. In section 2, the analysis will focus only on constructions where the temporal frame for quantification is an interval of the time axis (like e.g. the one expressed by last year). Data from Portuguese will be used to distinguish linguistically these constructions from those where unquantified events are described, like:

(2) O David visitou Roma o ano passado.

"the David visited Rome the year past"

David visited Rome last year.

Still in section 2, a formal semantic characterisation of temporally bounded quantification structures is provided, which evinces the differences between these structures and those expressing simple (inclusive) temporal location, like (2). In section 3, a broader view of temporally bounded quantification is offered, extending it to the wider range of adverbials exemplified in (1). Temporal phrases associated with the expression of pure frequency - like the Portuguese counterparts of English per year - will be analysed in some detail; a compositional analysis of frequency phrases like [n-times per unit-of-time] will be defended, according to which the phrase [per unit-of-time] in those sequences is distinguished, and its role compared to the role of the other types of adverbials exemplified in (1) (as expressions that set time frames for quantification). 


\section{Temporal circumscription of quantification $v s$. temporal location}

\subsection{The distribution of Portuguese desde-adverbials}

In previous work (cf. Móia 2000, 2001), I showed that Portuguese desde-adverbials - as, for that matter, the Spanish, French and Italian counterparts of English since-adverbials - are dependent on the presence of event quantification in the clause to which they apply, namely when telic events are involved ${ }^{1}$. Observe the contrast in grammaticality between the following two sentences, which differ only in the absence or presence of an explicit quantifier over events:

*O David visitou a mãe desde Janeiro.

"the David visited the mother since January"

David has visited his mother since January.

${ }^{\mathrm{OK}} \mathrm{O}$ David visitou a mãe cinco vezes desde Janeiro.

"the David visited the mother five times since January"

David has visited his mother five times since January.

Furthermore, I showed in that work that the relevant licensing quantification (in the matrix clause) need not be explicit quantification over events, via a phrase like $n$ times, as in (4). It may as well be indirect quantification over events (cf. e.g. Krifka 1990, Schein 1993, Eberle 1998), associated with different types of quantification, as illustrated in (6) through (12), below.

(i) distributive quantification over discrete objects

(5) *Este urso morreu no zoo de Lisboa desde Janeiro. "this bear died in-the zoo of Lisbon since January"

This bear has died in the zoo of Lisbon since January.

${ }^{\mathrm{OK}}$ Cinco ursos morreram no zoo de Lisboa desde Janeiro.

"five bears died in-the zoo of Lisbon since January"

Five bears have died in the zoo of Lisbon since January.

${ }^{\mathrm{OK}} \mathrm{O}$ David restaurou o altar da igreja matriz de cinco cidades desde Janeiro ${ }^{2}$.

"the David restored the altar of-the church matrix of five towns since January"

David has restored the altar of the parish church of five towns since January.

(ii) measure quantification over discrete objects or massive entities

${ }^{\mathrm{OK}}$ Oitenta por cento deste edifício foi restaurado desde Janeiro.

"eighty per cent of-this building was restored since January"

Eighty per cent of this building has been restored since January.

\footnotetext{
${ }^{1}$ The combination of Romance counterparts of since-adverbials with descriptions of atelic eventualities is not subject to the same restrictions. When this combination occurs, sentences involve typically a durative - rather than an inclusive - location reading (i.e. the situation is said to hold throughout the whole location interval - cf. e.g. Vlach 1993, Móia 2000):

(i) O David mora em Lisboa desde 1974.

"the David lives in Lisbon since 1974"

David has been living in Lisbon since 1974.

The durative location reading is irrelevant for the issues addressed in this paper and will be ignored henceforth. However, provided the right context, a temporal quantification structure of the type under analysis in this paper is also possible with atelic predicates - cf. (13) below.

${ }^{2}$ Notice that the quantifying element can occur in very deeply embedded positions, as this example shows.
} 
(9) ${ }^{\mathrm{OK}}$ Esta máquina reciclou cinco toneladas de detritos desde Janeiro.

"this machine recycled five tons of wastes since January"

This machine has recycled five tons of waste since January.

(iii) temporal measure quantification over atelic eventualities:

(10) ${ }^{\mathrm{OK}} \mathrm{O}$ David trabalhou neste projecto durante cerca de duzentas horas desde Janeiro.

"the David worked on-this project for around of two-hundred hours since January"

David has worked on this project for about two hundred hours since January.

(iv) quantification via exclusive operators, like só, the Portuguese counterpart of only (whose omission in the following sentence would yield ungrammaticality)

${ }^{\mathrm{OK}} \mathrm{O}$ David só escreveu este artigo desde Janeiro.

"the David only wrote this paper since January"

David has only written this paper since January.

(v) conjunction associated with an implicature of exhaustive enumeration (of the relevant entities), as in the following sentence which is grammatical only under the interpretation where the set of all relevant towns visited during the mentioned period is being listed

${ }^{\mathrm{OK}} \mathrm{O}$ David visitou Londres, Paris e Berlim desde Janeiro.

"the David visited London, Paris and Berlin since January"

David has visited London, Paris and Berlin since January.

Other types of licensing quantification structures, besides these five, have been identified in Móia (2000, 2001), but they will be ignored here, for the sake of simplicity.

The examples above involve a combination of desde-phrases with descriptions of telic events. Similar structures, however, can be obtained with atelic eventualities, if (i) the same type of quantification structure occurs and (ii) the tense of the main verb expresses anteriority to the temporal perspective point (as is the case, for instance, with the "pretérito perfeito simples" or the "pretérito mais-que-perfeito"):

${ }^{\mathrm{OK}}$ O David morou em Lisboa três vezes desde 1974.

"the David lived PERFECTIVE SIMPLE PAST in Lisbon three times since 1974"

David has lived in Lisbon three times since 1974.

The difference between the grammatical and the ungrammatical structures above can be described as follows. Structures that refer to single episodic (telic) events - like (3) or (5) yield ungrammaticality when combined with desde-phrases. Conversely, all grammatical examples with desde-phrases refer to sets of events made up of possibly discontinuous subevents (happening within the time frame set by the adverbial). Furthermore, one may note that ungrammaticality arises whenever - in similar examples - the interpretation of possibly discontinuous events is blocked. This may result from the use of an explicit expression - like the counterpart of all at once, in (14) - or from an inference based on world knowledge - as in (15), with the counterpart of $a$ bomb, but not with the counterpart of a bulldozer.

(14) *Esta máquina reciclou cinco toneladas de detritos de uma só vez desde Janeiro.

"this machine recycled five tons of wastes of one only time since January"

This machine has recycled five tons of waste all at once since January.

(15) a. *Uma bomba destruiu trinta por cento deste edifício desde Janeiro.

"a bomb destroyed thirty per cent of-this building since January"

A bomb has destroyed thirty per cent of this building since January.

b. ${ }^{\mathrm{OK}}$ Um buldózer destruiu trinta por cento deste edifício desde Janeiro.

"a bulldozer destroyed thirty per cent of-this building since January"

A bulldozer has destroyed thirty per cent of this building since January. 
Likewise, it may be observed that group - contrary to distributive - NPs with cardinal quantifiers do not license the use of desde-adverbials, because they are associated with single events rather than with sets of (possibly) distinct events. Thus, the following sentence, with a single-event group reading, is ungrammatical:

$$
\begin{aligned}
& \text { *O David ofereceu este quadro a três amigos desde Janeiro. [group reading] } \\
& \text { "the David offered this painting to three friends since January" } \\
& \text { David has offered the painting to three friends since January. }
\end{aligned}
$$

\subsection{Distinguishing temporal circumscription of quantification from temporal location}

In order to explain the distributional facts observed in section 2.1, I have argued that structures where temporal adverbials are associated with (explicit) quantification over eventualities - like (4), (6)-(12) or (13) above - are of a semantically distinct type from those where temporal adverbials merely provide a frame for locating (non-quantified) eventualities. In sum, two distinct constructions have to be taken into account:

- Temporal circumscription of quantification, or temporally bounded quantification

(full-scanning construction, in Móia 2000)

\section{- Temporal location}

The peculiarity of Portuguese desde-adverbials - or, more generally, of the Romance counterparts of since-adverbials - is that they are particularly sensitive to this distinction: the may define temporal boundaries for quantification, but they may not simply provide a frame for inclusive location ${ }^{3}$. Many other adverbials, however, readily occur in both types of constructions - cf. e.g. em Janeiro ('in January'):
(17)a. ${ }^{\mathrm{OK}} \mathrm{O}$ David visitou a mãe em Janeiro.
"the David visited the mother in January"
[temporal location]
David visited his mother in January.
b. ${ }^{\mathrm{OK}} \mathrm{O}$ David visitou a mãe cinco vezes em Janeiro. [circumscription of quantification] "the David visited the mother five times in January"
David visited his mother five times in January.

Temporal circumscription of quantification can be easily characterised within the framework of Discourse Representation Theory (DRT) defined in Kamp \& Reyle (1993). With regard to the data under analysis, the main point to note is that all the grammatical structures with desde-adverbials above involve abstraction over eventualities contained in the time frame set by the temporal adverbial. See the schematic representation, in the language of DRT, in (18), and the two illustrative DRS-representations - for sentences (4) and (6) - in (4') and (6') right afterwards, where Portuguese lexical items are translated for the sake of simplicity (cf. Móia 2000, for details):

\footnotetext{
${ }^{3}$ However, as said in fn. 1, they may provide a frame for durative location. The common fact between durative location and temporal circumscription of quantification is that, in both cases, the whole interval defined by the temporal adverbial is relevant (and this seems to be the requirement imposed by the Romance counterparts of since-adverbials): in sentences with a durative reading (like (i) in fn. 1), the described atelic eventuality is said to hold at all subintervals of the mentioned interval; in sentences with temporally bounded quantification, a reference is made to the sum of all the events of the mentioned type that occur within the relevant interval (whence, the whole interval has to be taken into account). In Móia (2000), I termed this construction fullscanning (inclusive location) in order to underline this idea (since, metaphorically speaking, it is as if the whole interval is scanned in order to gather the relevant events happening within it).
} 


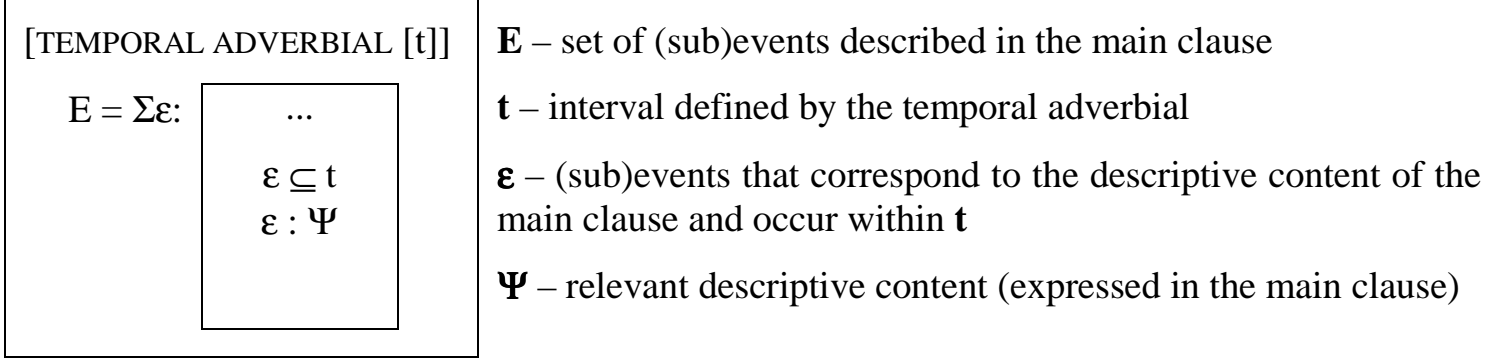

o David visitou a mãe cinco vezes desde Janeiro (David has visited his mother five times since January)

$(4)^{\prime}$

\begin{tabular}{|c|}
$\mathrm{E}=\Sigma \mathrm{e}:{ }^{[\text {since January }[\mathrm{t}]]}$ \\
$\begin{array}{c}\mathrm{e} \subseteq \mathrm{t} \\
\text { e: David visit his mother }\end{array}$ \\
\hline$|\mathrm{E}|=5$ \\
whence: $[\mathrm{E} \subseteq \mathrm{t}]^{4}$
\end{tabular}

cinco ursos morreram no zoo de Lisboa desde Janeiro (five bears have died in the zoo of Lisbon since January)

$(6)^{\prime}$

\begin{tabular}{|c|c|}
\hline \multirow[b]{2}{*}{$\begin{array}{l}\mathrm{Y}=\Sigma \mathrm{y}: \\
\mathrm{E}=\Sigma \mathrm{e}:\end{array}$} & [since January [t]] \\
\hline & $\begin{array}{c}\mathrm{e} \subseteq \mathrm{t} \\
\text { bear }(\mathrm{y}) \\
\mathrm{e}: \mathrm{y} \text { die in the zoo of Lisbon }\end{array}$ \\
\hline & $|Y|=5$ \\
\hline
\end{tabular}

The representation in (18) evinces the maximality requirement that distinguishes the structures under consideration. In fact, the relevant sentences refer to sets of events (E), more precisely the set of all subevents $\varepsilon$ that, on the one hand, correspond to the descriptive content in the matrix clause $(\Psi)$ and, on the other hand, happen within the time frame defined by the adverbial (t). This representation also evinces the peculiar role of temporal adverbials in these constructions: as can be seen, although they may appear in relatively high syntactic positions, temporal adverbials act here as true event modifiers, inasmuch as inclusion in the time frame set by them (t) is a defining property of the elements assembled in the sum represented by the main clause $(\mathbf{E})$ (witness the presence of the discourse referent $\mathbf{t}$ inside the sub-DRS!).

Temporal circumscription of quantification has several linguistic properties that set it apart from simple inclusive temporal location. Let us consider an outstanding one, by comparing the English sentences in (19) - which involve simple inclusive temporal location - with those in (20) - which involve temporally bounded quantification :

(19)a. David has visited his mother since January.

b. David visited his mother in January.

c. David offered this painting to (exactly) three friends in May 1995. [group reading]

(20)a. David has visited his mother five times since January.

b. David visited his mother five times in January.

c. David wrote (exactly) three essays in May 1995.

First, let us note that in (19), the events described in the main clause (David's visit to his mother or his offering of the mentioned painting) are defined independently of the locating interval. Differently, in the temporally bounded quantification structures of (20), as was underlined, the interval provided by the adverbial plays a role - as a kind of modifier - in defining the (complex) event represented in the main clause. A direct consequence of this

\footnotetext{
${ }^{4}$ Although these temporal adverbials may locate the complex event $(\mathrm{E})$ as a whole $-[\mathrm{E} \subseteq \mathrm{t}]-$ this function is, as it were, subsidiary, since its primary function is (arguably) to provide the frame for temporal quantification over eventualities $-[\ldots . .[\mathrm{e} \subseteq \mathbf{t}] \ldots]$ (cf. Móia 2000).
} 
difference is that, if the temporal frame associated with the adverbial is widened, truth preservation is not guaranteed in temporally bounded quantification structures, though it is caeteris paribus - in (inclusive) temporal location ones. See (22) and (21), where three is to be interpreted in all cases as a non-monotonic exact quantifier:

(21)a. David offered this painting to (exactly) three friends in May 1995. [group reading]

b. David offered this painting to (exactly) three friends in 1995.

(22)a. David wrote (exactly) three essays in May 1995.

b. David wrote (exactly) three essays in 1995.

From (21a), which involves simple inclusive location (in the group reading), it is possible to infer (21b). Conversely, from (22a), which involves temporally bounded quantification, the parallel inference, in (22b), is invalid. Sentences (23) and (24) below contain yet another interesting contrast, distinguishing the duration of telic and atelic eventualities:

(23)a. David prepared this project in (exactly) ten hours last Saturday.

b. David prepared this project in (exactly) ten hours last weekend.

(24)a. David worked on this project for (exactly) ten hours last Saturday.

b. David worked on this project for (exactly) ten hours last weekend.

From (23a) it is possible infer (23b). Conversely, (24a) does not allow the inference (24b). In the first case, the sentence refers to a single episodic event (David preparing the project in a given amount of time) that is located anywhere within the frame provided by last Saturday, i.e. the sentence involves simple inclusive location. In the second case, the sentence refers to the duration of the sum of all the (possibly discontinuous) subevents of David working on the project that happened within the temporal boundaries set by last Saturday, i.e. the sentence involves a "full-scanning" of the interval, or temporal circumscription of quantification. Thus, if the boundaries are different, the sum may be different as well.

Marginally, one may note a particular characteristic of the structures with temporally bounded quantification that possibly constitutes a pragmatic restriction. These structures are somewhat odd, or very odd, if the time boundaries are excessively vague (cf. Alves 2003):

(25) Este rio transbordou cinco vezes \{desde $1980 /$ ?? desde antes de 1980\}.

"this river overflowed five times \{ since 1980 / since before of 1980\}"

This river has overflowed its banks five times \{ since 1980 / since before 1980\}.

Curiously, no parallel contrast in grammaticality is observed (26), where (durative) temporal location is involved:

(26) Este rio está gravemente poluído \{desde 1980 / desde antes de 1980\}.

"this river is gravely polluted \{ since 1980 / since before 1980\}"

This river has been seriously polluted \{ since 1980 / since before 1980\}.

In connection with the type of pragmatic effect observed in (25), it may noted that (non-echo) interrogatives where temporal adverbials - as wh-constituents - are used to define temporal boundaries for quantification are also very odd:

(27) $\quad\{$ ? Quando / *Desde quando $\}$ é que este rio transbordou cinco vezes?

" $\{$ when / since when $\}$ is that this river overflowed five times?

\{When did this river overflow / Since when has this river overflowed \} its banks five times?

At this point, an issue must be stressed: temporally bounded quantification structures may arise with virtually any kind of (so-called) locating adverbial and not only with desdeadverbials. In fact, I assume that the event abstraction which distinguishes this construction 
(cf. (18)) is triggered by quantifying elements in the matrix structure and not by the temporal adverbials. Therefore, whenever these quantifying elements are present - together with an adverbial that identifies a time interval - the temporal circumscription construction may emerge. The specificity of the Portuguese desde-adverbials is thus merely that, when combined with descriptions of telic events, they may set boundaries for quantification, but they may not simply locate, whereas most other temporal adverbials may play both roles. (28) below contains several examples of the construction at stake with different time adjuncts (29) contains parallel examples involving simple (inclusive) temporal location:

(28) Foram descobertas trinta e cinco novas crateras de impacto

\{entre 1980 e 1985 / o ano passado / na década de 80 / desde Janeiro passado\}.

"were found thirty and five new craters of impact

\{between 1980 and 1985 / the year past / in-the decade of 80 / since January past\}"

Thirty five new impact craters were (have been) found

\{between 1980 and 1985 / last year / in the 80's / since last January\}.

(29) Esta cratera de impacto foi descoberta

\{entre 1980 e 1985 / o ano passado / na década de 80 / *desde Janeiro passado\}.

"this crater of impact was found

\{between 1980 and 1985 / the year past / in-the decade of 80 / since January past\}"

This impact crater was (has been) found

\{between 1980 and 1985 / last year / in the 80's / since last January\}.

\section{A broader view of temporal circumscription of quantification}

\subsection{Temporal circumscription of quantification with different types of adverbials}

All the examples given in section 2 contain adverbials that are traditionally classified as temporal locating (or frame) adverbials, since they define intervals of the time axis. Let us consider again two of these cases:

(30) a. O ministro falou com o presidente cinco vezes desde Janeiro.

"the minister spoke with the president five times since January"

The minister has spoken with the president five times since January.

b. O ministro falou com o presidente cinco vezes a semana passada.

"the minister spoke with the president times the week past"

The minister spoke with the president five times last week.

However, adverbials traditionally classified in other classes can also occur in constructions that involve temporally bounded quantification. First, we can mention a subset of adverbials, that might be classified as duration adverbials in some grammars, since they refer to amounts of time rather than to intervals of the time axis - e.g. Portuguese em mês e meio or em menos de três semanas, and its English counterparts in a month and a half or in less than three weeks, respectively:

\footnotetext{
${ }^{5}$ Cf. also the following English examples (involving different adverbials) from the British National Corpus: G2F 9 And, on average, we each do it five times in our life. | CH3 4927 Colin resents the notion that he doesn't carry a big punch and this could be a chance for him to try to prove otherwise as Palacio admits to having been knocked out four times in his 58-fight career. | CB2 1513 Roebuck revealed that his ankle dislocated no less than four times during the World Cup final. ECH 396 I have done the route a dozen or more times since that distant autumn, and (...) I have never set off across that huge ceiling without a feeling of apprehension. | FR5 1234 I only saw Stephen a few times before I went back to prison. | K1U 305 They plan to build another 40 houses over the next 10 years.
} 
(31) a. O ministro falou com o presidente cinco vezes em mês e meio.

"the minister spoke with the president five times in month and half"

The minister spoke with the president five times in a month and a half.

b. Em menos de três semanas, o ministro falou com o presidente cinco vezes ${ }^{6}$.

"in less of three weeks, the minister spoke with the president five times"

In less than three weeks, the minister spoke with the president five times.

These constructions are to be distinguished from those expressing simple duration, like:

O ministro escreveu este livro em mês e meio.

"the minister wrote this book in month and half"

The minister wrote this book in a month and a half.

Secondly, we can mention temporal adverbials that are often classified as frequency adverbials, or as adverbs of temporal quantification (cf. Kamp \& Reyle 1993), like Portuguese todos os fins-de-semana or its English counterpart every weekend:

O ministro falou com o presidente cinco vezes todos os fins-de-semana.

"the minister spoke with the president five times all the weekends"

The minister spoke with the president five times every weekend.

This construction involves temporally bounded quantification over events (expressed in the matrix structure), unlike the following parallel structure (that expresses simple temporal quantification, in the sense of Kamp \& Reyle 1993):

O ministro falou com o presidente todos os fins-de-semana.

"the minister spoke with the president all the weekends"

The minister spoke with the president every weekend.

Finally, we can observe temporally bounded quantification structures - of a comparable nature, I will argue - with adverbials that express pure frequency, like Portuguese cinco vezes por mês or its English counterpart five times a month (or per month):

O ministro falou com o presidente cinco vezes por mês.

"the minister spoke with the president five times per month"

The minister spoke with the president five times per month.

A specificity of constructions like (35) is that they do not have counterparts without quantification over eventualities. In other words, sequences like por mês / per month do not seem to combine with structures that do not involve explicit quantification:

*O ministro falou com o presidente por mês.

"the minister spoke with the president per month"

*The minister spoke with the president per month.

The consideration of all the different examples presented in this section offers a broader view of temporally bounded quantification than the one sketched in section $2^{7}$. My contention is

\footnotetext{
${ }^{6}$ Note that these adverbials, contrary to normal duration adverbials, readily occur in sentence initial-position.

${ }^{7}$ Cf. also the following English examples (involving different adverbials) from the British National Corpus: CM0 109 It is unusual for a major organisation to change its chief executive four times in less than a decade (...). | K3K 1697 Later, experts were divided over whether two horrific attacks in just five days meant more could be expected. | B03 3011 Although the house, originally a simple hall house, has been extended and altered at least five times over nearly 600 years, it still has an overall integrity (...).

GW0 259 There's a man with a Doberman comes around two or three times every night. | C96 2109 The powerheads should draw the whole volume of the tank through the filter bed at least three times each hour. | AS7 1742 Assynt is a good salmon loch with upwards of sixty fish being caught most seasons.
} 
that these structures, and in particular the temporal adverbials that occur in them, should be considered on a par, rather than scattered in independent semantic domains like location, duration, temporal quantification or frequency. Though intimately linked with those domains, these adverbials seem to share linguistic properties, which bring them together as phrases that express temporal circumscription of quantification.

\subsection{Common properties of structures with different types of adverbials}

First, let us start by noting that, formally, all the relevant structures might be considered to involve an abstraction over eventualities similiar to the one already described in section 2 . What happens is that the temporal frame involved in the abstraction may correspond to different temporal entities: (i) intervals of the time axis (in structures traditionally associated with the domain of temporal location or of temporal quantification); (ii) amounts of time (in structures traditionally associated with the domain of duration); (iii) time units (in structures traditionally associated with the domain of pure frequency). Any of this entities can be used as a temporal frame (t) for event-summation. Compare the schematic DRT-representations in (37)-(40).

(37)

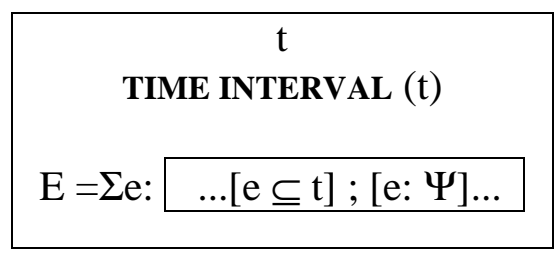

(38)

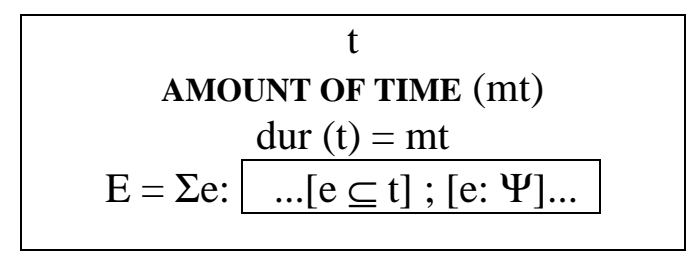

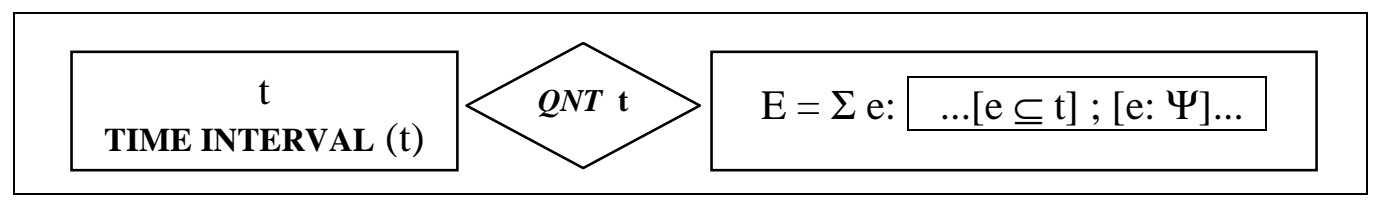

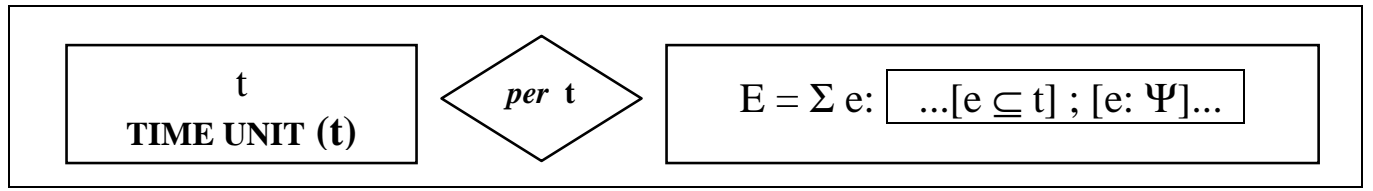

Naturally, structures with temporally bounded quantification can be divided in different subgroups according to the type of temporal frame used. On the one hand, each subgroup may have specific properties that need to be tackled separately (this is outstandingly the case with pure frequency constructions, like five time per month, as we will see later on). However, on the other hand, all these constructions have linguistic properties in common - cf. schemata (37)-(40) -, which call for a parallel analysis. As for these properties, I will only underline here the similarities in distribution, leaving other possible common properties for further research.

As a matter of fact, it should be noted that phrases that identify amounts of time, like in a week and a half, or time units, like per week - just like those that identify intervals of the time

K9J 181 If all goes according to plan, the $£ 60$ million investment will produce around 300,000 tonnes per year of ammonia at the lowest costs in Western Europe. | HL1 499 He also received a three-year period of probation --; during which he would be required to perform 1,800 hours of community service per year --; on a more general conspiracy charge.| G19 1229 The CCLGF meets six or seven times a year and is chaired by the Secretary of State for the Environment. 
axis, as last weekend or since January - may act as temporally binding expressions for indirect quantification over eventualities. They may, for instance occur, with

(i) distributive quantification over discrete objects (cf. (6) above)

(41)a. O David leu três livros no fim-de-semana passado.

"the David read three books in-the weekend past"

David read three books last weekend.

b. O David leu três livros numa semana e meia.

"the David read three books in-a week and half"

David read three books in a week and a half.

c. O David leu três livros por semana.

"the David read three books per week"

David read three books per week.

(ii) temporal measure quantification over atelic eventualities (cf. (10) above)

(42)a. O David trabalhou neste projecto durante mais de 60 horas a semana passada. "the David worked on-this project for more of 60 hours the week past"

David worked on this project for over 60 hours last week.

b. O David trabalhou neste projecto durante mais de 60 horas numa semana e meia.

"the David worked on-this project for more of 60 hours in-a week and half"

David worked on this project for over 60 hours in a week and a half.

c. O David trabalhou neste projecto durante mais de 60 horas por semana.

"the David worked on-this project for more of 60 hours per week"

David worked on this project for over 60 hours per week.

However, structures that express pure frequency (with por-phrases) have a more limited distribution. In particular, they are not licensed with event quantification associated with exclusive operators or with conjunction (cf. (11) and (12) above). This correlates with the fact that (possibly) the event abstraction associated with these operators is not directly asserted (rather being implied at some level).

(43)a. O David só escreveu este artigo \{desde Janeiro / num mês e meio\}.

"the David only wrote this paper \{ since January / in-a month and half\}"

David only wrote (has only written) this paper \{ since January / in a month and a half .

b. *O David só escreveu este artigo por mês.

"the David only wrote this paper per month"

*David only wrote this paper per month.

(44)a. O David visitou Londres, Paris e Berlim \{desde Janeiro / num mês e meio\}.

"the David visited London, Paris and Berlin \{ since January / in-a month and half\}"

David visited (has visited) London, Paris and Berlin \{ since January / in a month and a half\}.

b. *O David visitou Londres, Paris e Berlim por mês.

"the David visited London, Paris and Berlin per month"

*David visited London, Paris and Berlin per month.

It can also be noted that por-phrases exhibit distributional restrictions comparable to those of desde-phrases. More precisely, since por-phrases are only compatible with temporally bounded quantification, requiring event-iteration, the blocking effects resulting from coercion of a single-event reading (observed in (14) and (16), in section 2, apropos desde-phrases) also affect them: 
(45) *O David ofereceu este quadro a três amigos por semana. [group reading]

"the David offered this painting to three friends per week"

*David offered this painting to three friends per week.

(46) *O David comprou cinco descapotáveis ao mesmo tempo por mês.

"the David bought five convertibles at-the same time per month"

*David bought five convertibles at the same time per month.

\subsection{Por-adverbials: frequency and temporal circumscription of quantification}

It is implicit in what was said up to now that por-phrases in sequences like cinco vezes por mês ('five times per month') are being analysed autonomously, i.e. independently of the quantifying phrase (e.g. cinco vezes, 'five times') with which they combine. In fact, these phrases are taken to have a semantic role of its own, as they provide a temporal frame for quantification, along the same lines as adverbials that define time intervals or amounts of time. Given that, traditionally, sequences like cinco vezes por mês ('five times per month') are presented as an unanalysed whole - classified as an adverbial of frequency -, this 'splitting' analysis requires further justification. This is what I will attempt to do now.

The first thing to underline about the por-adverbials under consideration is that they may occur in two rather distinct types of syntactic contexts (just like, for that matter, their English counterparts with per or $a$ ).

O ministro fala/falou com o presidente cinco vezes por mês.

"the minister speaks/spoke with the president five times per month"

The minister speaks with the president five times per month.

O ministro faz/fez cinco discursos por mês.

"the minister makes/made five speeches per month"

The minister makes/made five speeches per month.

In the first sentence, the sequence por mês ('per month') is applied to the quantifier over events cinco vezes ('five times'), which occurs adverbially. In the second case, the same sequence is applied to the NP cinco discursos ('five speeches'), which is the direct object of the verb. In grammar books, only the first case is normally considered. There, as said, sequences like cinco vezes por mês ('five times per month') are normally considered as (unanalysed) units, and classified as adverbials of frequency (cf. e.g. Bennett \& Partee 1978, Quirk et al. 1985, or Huddleston \& Pullum 2002, for the English counterparts). No references are normally made to a possible internal analysis. Huddleston and Pullum (2002: 715), however, classify the counterparts of these por-phrases as "postmodifiers" (a category they oppose to "separate adjuncts") within the overall frequency phrase: "clear postmodifiers are NPs introduced by $a$ or else PPs with per as head".

I will advocate here that, both in adverbial contexts like (47) and in nominal contexts like (48), the sequence [n-times/n-objects por unit-of-time] is a constituent of the whole sentence and that it can have a compositional analysis, distinguishing the sequence [por unit-of-time] as an expression that sets temporal boundaries for event quantification, along the lines defined in the previous sections of this paper (cf. schema (40)).

Among the syntactic properties of the Portuguese sequences [n-times/n-objects por unit-oftime] that justify its analysis as a syntactic constituent - expressing frequency - we might emphasize: the possibility of topicalisation, of focussing, and of anaphoric reference via a relative pronoun (like $o$ que, 'what'), as shown in the following three sentences, respectively:

(49)a. Cinco discursos por mês, o ministro fez muitas vezes.

"five speeches per month, the minister made many times" 
b. Cinco discursos por mês é que o ministro devia fazer!

"five speeches per month [is that] FOCUS STRUCTURE the minister should make!"

c. Cinco discursos por mês é o que um ministro faz normalmente.

"five speeches per month is [the that $]_{=W H A T}$ a minister makes normally"

On the other hand, the por-adverbial alone has considerable syntactic autonomy: it can be topicalised, and it may occur in different positions in the sentence (separate from the quantified NP $n$-times / $n$-objects). Witness its position in the following examples:

(50)a. Por mês, o ministro faz cinco discursos.

b. O ministro faz por mês cinco discursos.

c. O ministro, por mês, faz cinco discursos.

Thus, at least in Portuguese, a compositional analysis of phrases of the type [n-times/n-objects por unit-of-time] seems defensible ${ }^{8}$. According to this analysis, the sequence [por unit-oftime] provides a temporal frame for event quantification along the lines of other temporal adverbials described in this paper. It should be noted however that, despite its relatively embedded syntactic position, this por-phrase often takes scope over the whole predicative content of the sentence (with some exceptions that I will not consider here ${ }^{9}$ ) - cf. DRSrepresentations of (53) and (54) below.

Furthermore, it must be underlined that, as has been often noted in the literature for the English counterparts of por-phrases, this subtype of structures has specific Aktionsart properties (cf. e.g. Moens 1987, or Huddleston and Pullum 2002). Sequences of the form [ntimes por unit-of-time] combine with event descriptions to form complex expressions which behave - as a whole - as atelic expressions (activities). In Portuguese, this explains why these expressions are compatible with (i) verb tenses expressing overlapping to temporal perspective points (e.g. present or imperfective simple past) - cf. (51) -, and (ii) temporal measure phrases headed by durante (the counterpart of English for) - cf. (52):

O ministro fala / falava com o presidente cinco vezes por mês.

"the minister speaks / spoke IMPERFECTIVE SIMPLE PAST with the president five times per month"

The minister speaks / used to speak with the president five times per month.

$\mathrm{O}$ ministro falou com o presidente cinco vezes por mês durante quase um ano.

"the minister spoke with the president five times per month for almost a year"

The minister spoke with the president five times per month for almost a year.

The following DRS-representations illustrate the compositional analysis sketched above ${ }^{10}$ :

\footnotetext{
${ }^{8}$ English per-phrases seem to behave similarly - cf. the following examples from the British National Corpus:

CRA 2668 Adding in refinancing of maturing debt (and allowing for individuals' national savings), that means that $£ 1$ billion of gilt-edged debt must be sold per week. | A7N 981 How much money do you spend on clothes (excluding shoes and lingerie) per month?

${ }^{9}$ The por-adverbial doesn't take scope over the predicative content of the matrix clause in some structures, e.g. when it is embedded in an NP with the counterparts of nouns like rhythm, pace, rate, speed, etc. (Note that, in these cases, it cannot be topicalised.)

(i) O estádio estava a ser evacuado a [NP um ritmo de [duzentas pessoas por minuto]].

"the stadium was to be evacuated at a pace of two-hundred persons per minute"

The stadium was being evacuated at [NP a pace of [two hundred people per minute]].

${ }^{10}$ Two notes about these representations:

(i) I will not attempt to provide here the semantics of the quantifier por. On the one hand, this quantifier is roughly similar to a universal quantifier. On the other hand, however, it often implies an average value (even when the explicit sequence em média ('in average'), is absent).
} 
(53) O ministro fala com o presidente cinco vezes por mês.

"the minister speaks with the president five times per month"

The minister speaks with the president five times a month.

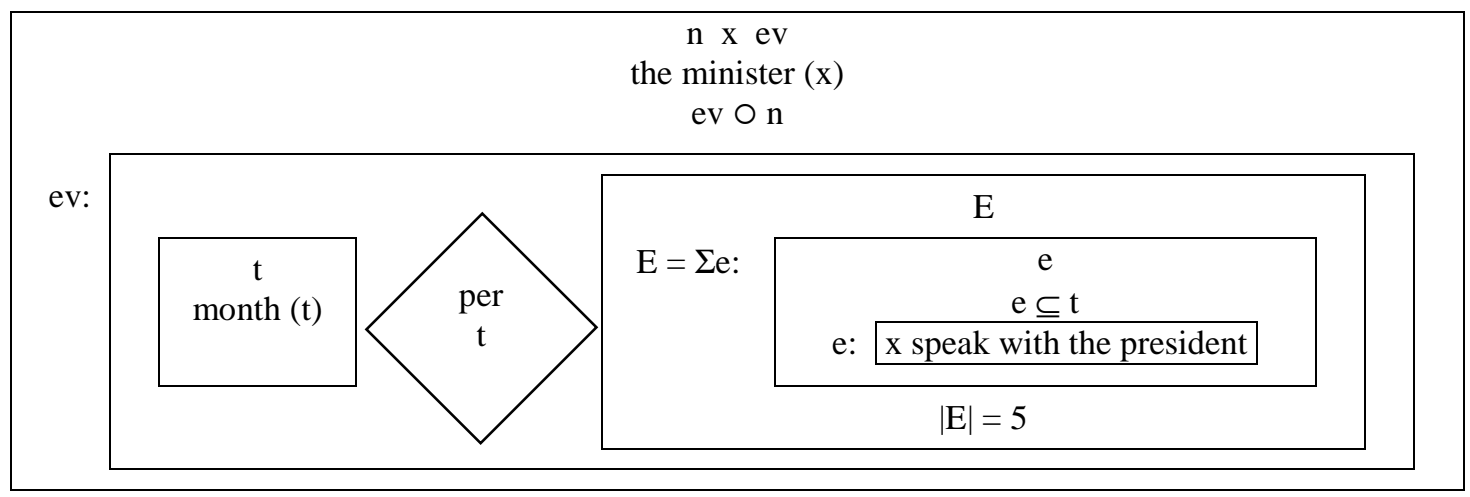

(54) O ministro faz cinco discursos por mês.

"the minister makes five speeches per month"

The minister makes five speeches a month.

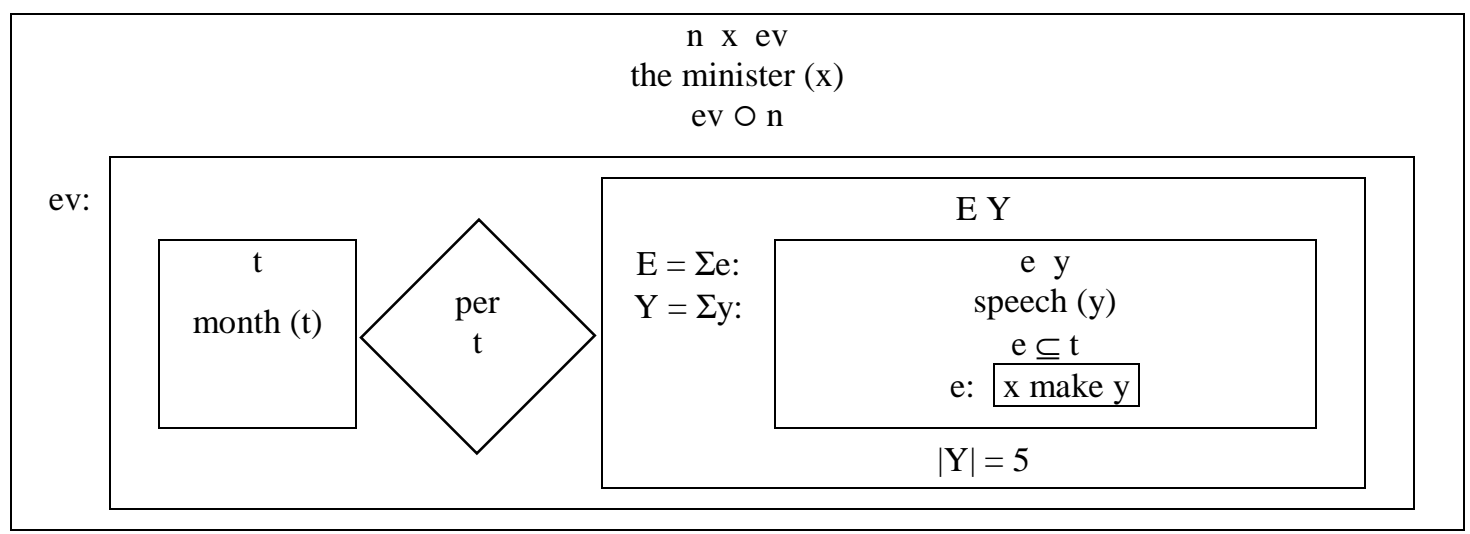

Note that the discourse referent associated with the por-adverbial (t) occurs within the subDRS associated with the event-abstraction (in the condition $[e \subseteq t]$ ). Therefore, considered on its own (irrespective of the fact that it is part of a larger constituent expressing frequency), the por-adverbial defines a temporal frame for event quantification, and is thus comparable to the other temporal adverbials analysed in this paper (e.g. inclusive desde-adverbials).

\section{Conclusion}

In this paper I attempted to identify of a set of constructions where quantification over eventualities expressed in a matrix clause directly depends on a temporal parameter expressed by a temporal adverbial. In constructions with adverbials that identify a time interval or an amount of time (e.g. desde 1995 / since 1995, em 1995 / in 1995 or em menos de dois meses / in less than two months), the main role of the adverbial is, arguably, to provide a frame for event quantification, rather than to locate, or to express duration. In constructions with adverbials that identify time units (e.g. por mês / per month), the main role of the adverbial is to contribute to the expression of a frequency value in combination with a quantified phrase (e.g. cinco vezes / five times or cinco discursos / five speeches). However, a compositional analysis of frequency adjuncts seems defensible, according to which the isolated per-phrase

(ii) The fact that sequences with por-phrases behave as atelic predicates is symbolised in the condition ev: $\alpha$, where $\alpha$ is a duplex condition. The discourse referent ev represents the complex eventuality - an activity - of doing something with a certain frequency (for Aktionsart shift in DRT, cf. Swart 1998). 
has a contribution of its own, viz. to set temporal boundaries for quantification along similar lines as the adverbials that define time intervals or amounts of time.

This paper considered mainly data from Portuguese, although the issue at stake - the evidence for a close interaction between temporal adverbials and event structure in some specific type of structures - has certainly a more general relevance.

\section{References}

Alves, Ana Teresa: 2003, Sobre a Localização Temporal Adverbial Anafórica em Português, Ph.D. thesis, Universidade dos Açores, Ponta Delgada.

Bach, Emmon: 1986, The Algebra of Events, Linguistics and Philosophy 9, 5-16.

Eberle, Kurt: 1998, The Influence of Plural NPs on Aktionsart in DRT, in Fritz Hamm and Erhard Hinrichs (eds.), Plurality and Quantification, Dordrecht: Kluwer Academic Publishers, pp. 55-111.

Huddleston, Rodney \& Geoffrey Pullum: 2002, The Cambridge Grammar of the English Language, Cambridge: C.U.P.

Kamp, Hans \& Uwe Reyle: 1993, From Discourse to Logic. Introduction to Modeltheoretic Semantics of Natural Language, Formal Logic and Discourse Representation Theory, Dordrecht: Kluwer.

Krifka, Manfred: 1990, Four Thousand Ships Passed through the Lock: Object-Induced Measure Functions on Events, Linguistics and Philosophy 13, 487-520.

Moens, Marc: 1987, Tense, Aspect and Temporal Reference, Ph.D. thesis, University of Edinburgh (reproduced by the Centre for Cognitive Science, University of Edinburgh).

Móia, Telmo: 2000, Identifying and Computing Temporal Locating Adverbials with a Particular Focus on Portuguese and English, Ph.D. thesis, University of Lisbon. [available at http://www.fl.ul.pt/dlgr/pessoais/tmoia/index.html]

Móia, Telmo: 2001, Temporal Location of Events and the Distribution of the Romance Counterparts of Since-Adverbials, in Joaquim Camps and Caroline Wiltshire (eds.), Romance Syntax, Semantics and L2 Acquisition, Selected papers from the $30^{\text {th }}$ Linguistic Symposium on Romance Languages, Gainesville, Florida, February 2000, Amsterdam: John Benjamins, pp. 137-152.

Quirk, Randolph et al.: 1985, A Comprehensive Grammar of the English Language, London: Longman.

Rothstein, Susan: 1995, Adverbial Quantification over Events, Natural Language Semantics 3, 1-31.

Schein, Barry: 1993, Plurals and Events, Cambridge, Massachusetts: The MIT Press.

Swart, Henriëtte de: 1998, Aspect Shift and Coercion, Natural Language and Linguistic Theory 16, 347-385.

Vlach, Frank: 1993, Temporal Adverbials, Tenses and the Perfect, Linguistics and Philosophy 16, 231-283. 